\title{
Nucleic acid-binding specificities of tobacco chloroplast ribonucleoproteins
}

\author{
Yuqing $\mathrm{Li}$ and Masahiro Sugiura* \\ Center for Gene Research, Nagoya University, Chikusa, Nagoya 464-01, Japan
}

Received March 14, 1991; Revised and Accepted May 8, 1991

\begin{abstract}
Many ribonucleoproteins (RNPs) are involved in the regulation of gene expression at the posttranscriptional level. We previously isolated three nuclear-encoded RNPs from tobacco chloroplasts. Here we report their binding specificities for various nucleic acids. The three RNPs synthesized in vitro were subjected to binding assays using SsDNA, dsDNA and four ribonucleotide homopolymers. The affinities for ribonucleotide homopolymers are higher than those for ssDNA and dsDNA, suggesting that they bind preferentially to RNA in vivo. All three RNPs show high specificities for poly(G) and poly(U) in the presence of $1.2-1.8 \mathrm{M} \mathrm{NaCl}$, providing additional evidence for the similarity to HeLa hnRNP proteins. Possible involvement of these RNPs in the post-transcriptional regulation of chloroplast gene expression is discussed.
\end{abstract}

\section{INTRODUCTION}

Chloroplasts contain their own genetic system $(1,2)$ and their gene expression is light and developmentally regulated at the transcriptional and post-transcriptional levels (3-7). Many ribonucleoproteins (RNPs) are known to be involved in the splicing, processing and stabilizing of transcripts (reviewed in 8-13).

We have identified three RNPs (cp28, cp31, cp33) from tobacco chloroplasts $(14,15)$. These proteins were isolated based on a purification procedure developed for HeLa cell hnRNP proteins $(16,17)$, which uses an ssDNA affinity column. Sequence analysis of their cDNAs revealed that all three proteins contain two ribonucleoprotein consensus sequences (RNP-CS, reviewed in 8,10,11). Based on the presence of highly conserved RNPCS motifs and the affinity for ssDNA, we concluded that they are RNPs (14). However, direct experimental evidence is necessary to show that these RNPs really bind to RNA.

The three chloroplast RNPs show several structural similarities to hnRNP proteins and we speculated that these proteins play similar roles as hnRNP proteins and are involved in the splicing and/or processing of chloroplast RNAs (14). Swanson and Dreyfuss developed a procedure for the classification and purification of HeLa cell hnRNP proteins by binding to four ribonucleotide homopolymers at various salt concentrations (18). They showed that several hnRNP proteins do have RNA-binding specificities; e.g. the hnRNP C proteins are poly(U)-binding proteins. We applied the binding procedure to the three chloroplast RNPs synthesized in vitro and compared their binding to ssDNA, dsDNA and four ribonucleotide homopolymers. These proteins bind preferentially to RNA and display very high affinities for poly(U) and poly $(\mathrm{G})$, providing additional evidence for the similarity to HeLa hnRNP proteins.

\section{MATERIALS AND METHODS}

\section{Construction of expression plasmids}

Expression plasmids were constructed essentially according to Hemsley et al. (19). Two PCR primers containing portions of the 5'-leader [68 nucleotides(nt)] of TMV RNA (20) and of the termini of KpnI-cut Bluescript $\mathrm{KS}(+)$ (Stratagene) were synthesized (TMV RNA parts are underlined and numbered from its $5^{\prime}$-end, and the initiation codon is indicated by $*$ ):
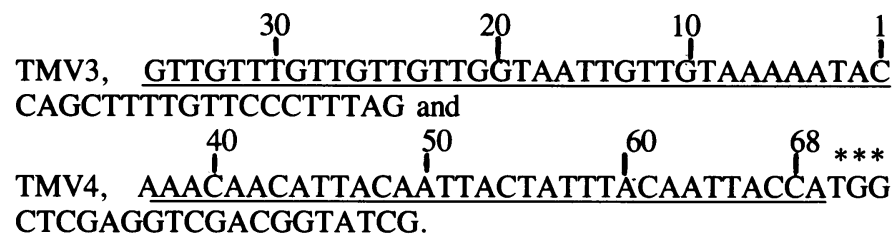

The original TMV sequence ACA ÂU $^{*} G$ was mutated to ACCÂ ${ }^{*}{ }^{*} G$ to create a $N c o I$ site and to fit the optimal sequence (ACCAUGG) for the initiation by eukaryotic ribosomes (21). PCR was performed as described (14) using KpnI-cut Bluescript $\mathrm{KS}(+)$ as template and 5'-phosphorylated TMV3 and TMV4 primers. The amplified product was treated with Klenow enzyme and ligated. Transcripts produced by T3 RNA polymerase contain a leader sequence of $81 \mathrm{nt}$ (a $13 \mathrm{nt}$ leader sequence from the transcription start site to a kpnI site and the 68 nt TMV RNA leader).

DNA fragments coding for the mature proteins of cp28, cp31 and $\mathrm{cp} 33$ were prepared by PCR using their cloned cDNAs [in Bluescript SK(+) and $\mathrm{KS}(+), 14]$ as templates. The PCR primers used were [restriction sites created for cloning are underlined]: 
cp28: $\operatorname{exp4~=~GCTCGAGTATTATCTGAAGATGAC,~and~}$ SK = TCTAGAACTAGTGGATC

cp31: $\exp 3=$ GCTCGAGCACTGCAAGAAGAAGAAA, and SK = TCTAGAACTAGTGGATC

cp33: $\operatorname{exp5~=~GCCATGGCTTCTGTGTCTGATGGA,~and~}$ $\mathrm{KS}=$ CGAGGTCGACGGTATCG

Vent ${ }^{\mathrm{TM}}$ DNA polymerase (New England BioLabs) was used to increase the fidelity of the PCR process. The amplified fragments were cut with $X h o I / E c o$ RI (for $c p 33, N c o I / E c o R I$ ), purified by $2 \%$ agarose gel electrophoresis and ligated after the TMV leader at either XhoI or NcoI site. The sequences encoding cp28, cp31 and cp33 (plasmids pTMV28K, pTMV31K and pTMV33K) were verified by DNA sequencing. The $\mathrm{N}$-terminal sequences of in vitro synthesized proteins (the authentic $\mathrm{N}$-terminal sequences are underlined) are: cp28: MARVLSEDDNTL-; cp31: MARALQEEENTL- and cp33: MASVSDGVEV-.

\section{In vitro protein synthesis}

Plasmid DNAs were linearized with EcoRI, treated with proteinase $\mathrm{K}$ and extracted with phenol-chloroform. Capped transcripts were produced using a mRNA capping kit (mCAPTM kit, Stratagene) at $37^{\circ} \mathrm{C}$ for $30 \mathrm{~min}$ in $25 \mu \mathrm{l}$ reaction containing $40 \mathrm{mM}$ Tris- $\mathrm{HCl}$ (pH 7.5), $50 \mathrm{mM} \mathrm{NaCl}, 8 \mathrm{mM} \mathrm{MgCl} 2,2 \mathrm{mM}$ spermidine, $400 \mu \mathrm{M}$ each of rUTP, rCTP and rATP, $120 \mu \mathrm{M}$ rGTP, $300 \mu \mathrm{M} 5^{\prime} 7 \mathrm{meGppp5}$ ', $30 \mathrm{mM}$ DTT, $1 \mu \mathrm{g}$ of DNA template, 1 unit of Inhibit-ACE (5 Prime $\rightarrow 3$ Prime, Inc.), 10 units of T3 RNA polymerase. The DNA template was then digested at $37^{\circ} \mathrm{C}$ for another $5 \mathrm{~min}$ with 10 units of RNase- free DNase. The transcripts were extracted with phenol-chloroform and precipitated with ethanol. The final pellet ( $\sim \mu \mathrm{g}$ RNA) was dissolved in $10 \mathrm{mM}$ Tris- $\mathrm{HCl}, \mathrm{pH} 7.5$ and $0.1 \mathrm{mM}$ EDTA.

Translation was performed at $30^{\circ} \mathrm{C}$ for $1.5-2 \mathrm{hr}$ in $50 \mu \mathrm{l}$ reaction containing $7 \mu \mathrm{l}$ of ${ }^{35}$ S]methionine (specific activity $\sim 1000 \mathrm{Ci} / \mathrm{mmole}, 70-106 \mu \mathrm{Ci}), \sim 0.9 \mu \mathrm{g}$ of capped RNA and $40 \mu \mathrm{l}$ of rabbit reticulocyte lysate (Amersham, N.90). Following the addition of BSA (DNase- and RNase-free, TaKaRa), Micrococcal nuclease (Boehringer Mannheim), $\mathrm{NaCl}$ and $\mathrm{CaCl}_{2}$ to final concentrations of $1 \mathrm{mg} / \mathrm{ml}, 100$ units $/ \mathrm{ml}, 100 \mathrm{mM}$ and $1 \mathrm{mM}$, respectively, the mixture was incubated for another 10 min. EGTA was added to a final concentration of $5 \mathrm{mM}$ to inactivate the nuclease. The products were frozen immediately and stored at $-70^{\circ} \mathrm{C}$.

\section{Preparation of a nuclease-treated chloroplast lysate}

Intact chloroplasts were prepared from Nicotiana sylvestris as described (14) and stored at $-70^{\circ} \mathrm{C}$. Chloroplasts prepared from $\sim 500 \mathrm{~g}$ leaves were homogenized in $20 \mathrm{ml}$ chilled buffer $\mathrm{A}(14)$. The homogenate was centrifuged at $28,000 \times \mathrm{g}_{\max }$ and $2^{\circ} \mathrm{C}$ for $30 \mathrm{~min}$. The supernatant was treated with micrococcal nuclease as above (BSA was omitted).

\section{Nucleic acid-binding assays}

Binding assays were done essentially according to Swanson and Dreyfuss (18). Solid $\mathrm{NaCl}$ was added to aliquotes $(0.3 \mathrm{ml})$ of the chloroplast lysate to increase their $\mathrm{NaCl}$ concentrations to $0.5,1$ and $2 \mathrm{M}$, and Triton $\mathrm{X}-100$ was added to $0.5 \%$. One to $5 \mu \mathrm{l}$ of the translation products were mixed with $0.3 \mathrm{ml}$ of binding buffer $\left(10 \mathrm{mM}\right.$ Tris- $\mathrm{HCl}, \mathrm{pH} 7.6,2.5 \mathrm{mM} \mathrm{MgCl}_{2}, 0.5 \%$ Triton $\mathrm{X}-100,1 \mu \mathrm{g} / \mathrm{ml}$ pepstatin, $1 \mathrm{mM}$ PMSF and $0.1,0.5,1$ or $2 \mathrm{M}$ $\mathrm{NaCl}$ ) or with $0.3 \mathrm{ml}$ of the chloroplast lysate with the indicated $\mathrm{NaCl}$ concentration $(0.1 \mathrm{M}, 0.5 \mathrm{M}, 1 \mathrm{M}$ or $2 \mathrm{M})$. The mixture was then incubated with $20 \mu \mathrm{l}$ of poly(G), poly(A), poly(U), or poly $(C)$, each of which had been bound to Sepharose beads (type 6, Pharmacia; 1 to $1.5 \mathrm{mg}$ of polymers per $\mathrm{ml}$ of swollen Sepharose beads). The beads were then spun down briefly and washed successively with $1 \mathrm{ml}$ binding buffer with the indicated $\mathrm{NaCl}$ concentration plus $2 \mathrm{mg}$ heparin (porcine intestinal mucosa, grade I; Sigma) and four times with the same buffer $(1 \mathrm{ml})$ without heparin. All incubation and washing were done at $4^{\circ} \mathrm{C}$ for $10 \mathrm{~min}$ using a rotator to ensure adequate end-over-end mixing. The drained beads were then heated for 2-3 min at $100^{\circ} \mathrm{C}$ in $50 \mu \mathrm{l}(100 \mu \mathrm{l}$ for the chloroplast lysate) of sample buffer (22), and $14 \mu$ l each of released protein samples were separated on a $0.1 \%$ SDS $/ 12.5 \%$ polyacrylamide gels (22). The gels were then treated with $\mathrm{EN}^{3} \mathrm{HANCE}$ (NEN) for fluorography, dried and exposed to Hyperfilm ${ }^{\mathrm{TM}}$ (Amersham) at $-70^{\circ} \mathrm{C}$ for $10 \mathrm{hr}$ to 4 days. For detection of total chloroplast proteins, a silverstaining kit (2D-silver stain -II, Daiichi Pure Chemicals) was used.

DNA-binding assays were the same as above using $20 \mu \mathrm{l}$ each of swollen cellulose $(174 \mathrm{mg} / \mathrm{ml}$, Whatman CF11, washed with $\mathrm{HCl}$ and $\mathrm{NaOH})$, ssDNA-cellulose $(0.75-1.5 \mathrm{mg}$ ss calf thymus DNA $/ \mathrm{ml}$, Sigma) or dsDNA-cellulose $(0.75-2 \mathrm{mg}$ ds calf thymus DNA/ml, Sigma).

\section{RESULTS}

\section{DNA-binding assays}

To obtain efficient in vitro synthesis of the RNPs, we used a translational enhancer sequence from the 5'-leader of TMV RNA (20). The $\left[{ }^{35} \mathrm{~S}\right]$-labeled RNPs were mixed and incubated with cellulose, ssDNA-cellulose, or dsDNA-cellulose at 0.1-2 M $\mathrm{NaCl}$ concentrations. A wash with heparin (nucleic acid competitor) was included to ensure that the binding is not due to electrostatical interaction $(17,23)$.

Figure 1 shows that the three RNPs (cp28, cp31 and cp33) remain bound to both ssDNA- and dsDNA-cellulose up to 0.5 $\mathrm{M} \mathrm{NaCl}$ and the binding is heparin resistant. No binding was observed when cellulose was used. The results suggest that the in vitro synthesized RNPs are functional and interact with DNA directly and independently. At $1 \mathrm{M} \mathrm{NaCl}$, a small fraction of cp28 and cp31 remains bound to DNA but not cp33. This fits our previous observation about the affinity order for $\mathrm{ssDNA}$, i.e., cp28 > cp31 > cp33 (14). Another interesting feature is that all RNPs bind also to dsDNA-cellulose. In fact at $0.1 \mathrm{M} \mathrm{NaCl}$, their affinities to dsDNA is stronger than those to ssDNA as judged from the intensity of bands.

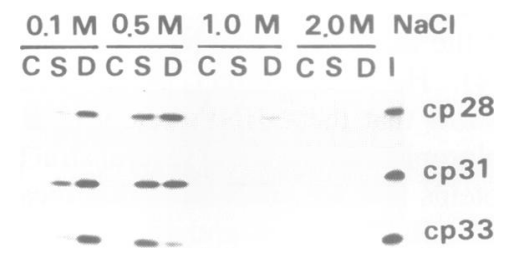

Figure 1. Binding of $\mathrm{cp} 28, \mathrm{cp} 31$ and $\mathrm{cp} 33$ to DNA. The $\left[{ }^{35} \mathrm{~S}\right]$ proteins were incubated with cellulose (C), ssDNA-cellulose (S) and dsDNA-cellulose (D) at $0.1-2.0 \mathrm{M} \mathrm{NaCl}$. The bound proteins were eluted and electrophoresed in polyacrylamide gels. Lane ' $I$ ' is a control to show the amount of proteins if complete binding occurred. 


\section{Ribonucleotide homopolymer-binding assays}

As shown in Figure 2A, clear binding preferences for ribonucleotide homopolymers were observed even at $0.1 \mathrm{M}$ $\mathrm{NaCl}$; all RNPs bind to poly(G) and poly(U) but not to poly(A), and cp28 and cp31 but not cp33 bind weakly to poly(C). All three RNPs remain bound to poly(G) and poly(U) up to $1 \mathrm{M} \mathrm{NaCl}$. At $2 \mathrm{M} \mathrm{NaCl}$, a weak binding to poly(G) and poly(U) was observed for all RNPs except cp33 to poly(U) (Figure 2A). Judged from the band intensity, we concluded that the affinities of three RNPs are poly(G) $\geq \operatorname{poly}(\mathrm{U})$ at $2 \mathrm{M} \mathrm{NaCl}$.

To investigate further the differences in binding to poly(G) and poly(U), we carried out additional binding experiments at $\mathrm{NaCl}$ concentrations from 1.2 to $1.8 \mathrm{M}$. Figure 2B shows additional features though only a fraction of added proteins were bound. First, the ability to discriminate between poly $(\mathrm{G})$ and poly(U) is different among the three RNPs. At $1.5 \mathrm{M}$ (and $1.8 \mathrm{M}$ ) $\mathrm{NaCl}$, cp33 preferentially binds to poly(G). The discrimination ability of cp28 is less prominent while no apparent discrimination was observed for $\mathrm{cp} 31$. Second, the affinity to poly(G) and poly(U) is in the order of cp31 $\simeq$ cp28 $>$ cp33. This fits the order of the elution from an ssDNA column (14), again supporting that the binding of RNPs to ssDNA is a faithful model for RNAbinding (24-26).

We performed the above binding assay in the presence of a chloroplast lysate to know whether the above results reflect the binding in vivo. The results showed that the binding pattern is essentially similar to that without the lysate. However the affinity of cp28 and cp31 at $2 \mathrm{M} \mathrm{NaCl}$ is poly(U) > poly(G) instead of poly $(\mathrm{G}) \simeq \operatorname{poly}(\mathrm{U})$ observed without the lysate (Figure 3A).

The chloroplast proteins bound to ribonucleotide homopolymers were also detected by staining. Figure 3B shows that there are more poly $(\mathrm{U})$ - and poly $(\mathrm{G})$-binding proteins than poly(A)- and poly(C)-binding proteins reminiscent of the binding pattern of HeLa nucleoplasm proteins (18). Another interesting feature is that about 20 proteins ranging from 20 to $120 \mathrm{kd}$ bound to poly(G) and poly(U) at 0.1 to $1 \mathrm{M} \mathrm{NaCl}$. These proteins might be components of the chloroplast genetic system. Among them seven or more protein species are around $30 \mathrm{kd}$ in size. Two

A $\frac{\mathrm{G}}{0.10 .51 .02 .0} \frac{\mathrm{A}}{0.10 .51 .02 .0} \frac{\mathrm{U}}{0.10 .510^{2.0}} \frac{\mathrm{C}}{0.10 .5102 .0}$

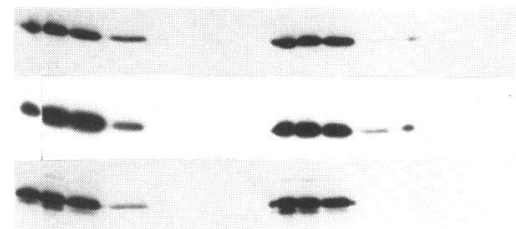

cp 28

cp 33

B

$$
\begin{aligned}
& \begin{array}{lll}
1.2 \mathrm{M} & 1.5 \mathrm{M} \quad 1.8 \mathrm{M} \mathrm{NaCl}
\end{array} \\
& \text { I } \overline{G U} \overline{G U} \overline{G U} \\
& \text { - - - - - cp28 } \\
& \text { - - - - - cp31 } \\
& \text { - - } \quad \text { ср } 33
\end{aligned}
$$

Figure 2. Binding of $\mathrm{cp} 28, \mathrm{cp} 31$ and $\mathrm{cp} 33$ to ribonucleotide homopolymers. The $\left[{ }^{35} \mathrm{~S}\right]$ proteins were incubated with poly $(\mathbf{G})-$, $\operatorname{poly}(\mathbf{A})-$, poly $(\mathbf{U})$ - and poly $(\mathbf{C})-$ Sepharose beads ( $G, A, U$ and $\mathbf{C}$, respectively) at $0.1-2.0 \mathrm{M} \mathrm{NaCl}$. The bound proteins were eluted and electrophoresed in polyacrylamide gels. Lane ' $\mathbf{I}$ ' is a control as in Fig. 1. lines of evidence suggest that they are likely to be members of the chloroplast RNP family (15). We found cp31 in protein fractions bound to poly(G) and poly(U) beads by $\mathrm{N}$-terminal protein sequencing after gel separation (data not shown). Second, five proteins in the above fraction reacted to the antisera raised against cp28 and cp31 (unpublished).

\section{DISCUSSION}

We have shown that the three chloroplast RNPs remain bound quantitatively to poly(G) and poly(U) up to $1 \mathrm{M} \mathrm{NaCl}$ (Figure 2A) while to DNA only up to $0.5 \mathrm{M} \mathrm{NaCl}$ (Figure 1). These data indicate that the three RNPs bind preferentially to ribonucleotide homopolymers, confirming that they are RNA-binding proteins and resemble HeLa hnRNP proteins. The substantial affinity for dsDNA suggests that these RNPs bind to paired parts of chloroplast RNAs in vivo. A likely binding site is the stem parts which have been shown to be processing signals for precursor RNAs and to stabilize the mRNAs in a chloroplast extract in vitro $(27,28)$.

The three RNPs show differential ribonucleotide homopolymer binding between cp28/cp31 and cp33 (Figure 2A). They are
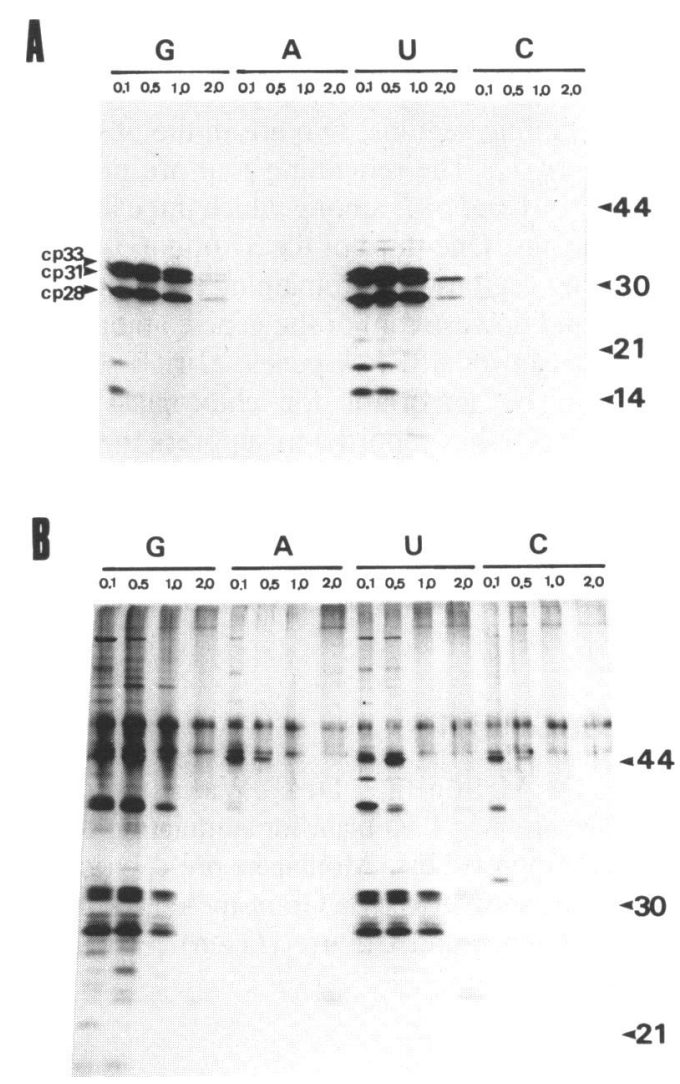

Figure 3. (A) Binding of cp28, cp31 and $\mathrm{cp} 33$ in the presence of a chloroplast lysate to ribonucleotide homopolymers. The chloroplast lysate was mixed with the $\left.{ }^{35} \mathrm{~S}\right]$ proteins and incubated with poly(G)-, $\operatorname{poly}(\mathbf{A})-$, $\operatorname{poly}(\mathbf{U})$ - and poly(C)Sepharose beads (G, A, U and $\mathrm{C}$, respectively) at $0.1-2.0 \mathrm{M} \mathrm{NaCl}$. The bound proteins were eluted and electrophoresed in polyacrylamide gels. Arrows on the right indicate MW markers in kd. Two proteins of 14-20 kd are likely to be partial length proteins resulted either from aborted synthesis or from internal initiation. (B): Silver staining patterns of ribonucleotide homopolymer-binding proteins from the chloroplast lysate. The binding was carried out as A without the $\left[{ }^{35} \mathrm{~S}\right]$ proteins. MW markers are on the right in $\mathrm{kd}$. 
encoded each by a single-copy gene while they show high global homology to each other and the same domain arrangement $(14,15)$. These observations suggest that the diversification of chloroplast RNP genes is necessary for the wide spectrum of binding specificities.

Comparison of the binding patterns with and without a chloroplast lysate revealed that the binding of cp31 and cp28 for ribonucleotide homopolymers are shifted from $\operatorname{poly}(G) \geq$ poly $(U)$ to poly $(U)>\operatorname{poly}(G)$. This change indicates that cp28 and cp31 interact with other chloroplast proteins in vivo.

$\mathrm{Cp} 33$ is a poly(G)/poly(U)-binding protein and is a poly(G)binding protein at higher $\mathrm{NaCl}$ concentrations. The binding preference is less clear for cp28 and cp31 (Figure 2A and Figure 3A). The results obtained with the chloroplast lysate should be closer to the physiological conditions and we concluded that cp28 and cp31 are poly(G)/poly(U)-binding proteins and show a slight preference for poly(U) at high $\mathrm{NaCl}$ concentrations.

The binding specificities of the RNPs provide clues for further investigation of their in vivo function. One advantage of working with the tobacco chloroplast system is that the entire sequence of this chloroplast genome has been determined (29) and the expression of thisi circular genome has been studied intensively (30). Computer search of the entire tobacco chloroplast DNA sequence revealed that there are $12 \mathrm{G}$-clusters ( $\geq 7 \mathrm{Gs}$ ) and about $110 \mathrm{~T}$-clusters ( $\geq 7 \mathrm{Ts}$ ). When transcription of these sequences are considered, they would only produce 11 oligo(rG) and 37 oligo(U) sequences. Among the 11 oligo(rG) sequences, five are located within coding regions, two are in the upstream regions of $r p s 2$ and $3^{\prime}-r p s 12$. The remaining four are in the introns of rps16, rpoC1, trnA and trnI, among which three are located near the $3^{\prime}$ end of introns. One-third of the 37 oligo(U) sequences are located in coding regions. The remaining two-thirds are located just upstream and downstream of the genes, among which 9 are located downstream of 8 tRNA genes. U-rich sequences have been shown to be important for chloroplast RNA-protein interaction. Poly(U) was reported to suppress the interaction of 3 'region of a trnK transcript with chloroplast proteins (31) and to inhibit the processing reaction involving 3 'inverted repeats of pet $D$ and $p s b A$ RNA precursors $(27,28)$. Whether the three chloroplast RNPs are involved in these reactions remains to be investigated.

\section{ACKNOWLEDGMENTS}

We thank Dr.M.Sugita, Dr.T.Wakasugi, Ms.L.Ye, Dr.A.Watanabe and Mr.T.Konishi for stimulating discussion and help. Y.Li was supported by a Monbusho pre-doctoral fellowship. This research was supported by a Grant-in-Aid from the Ministry of Education, Science and Culture (Japan).

\section{REFERENCES}

1. Sugiura, M. (1989) Annu. Rev. Cell Biol., 5, 51-70.

2. Palmer, J.D. (1990) Trends Genet., 6, 115-120.

3. Mullet, J.E. (1988) Annu. Rev. Plant Physiol. Plant Molec. Biol., 39, $475-502$.

4. Gruissem, W. (1989) Cell, 56, 161-170.

5. Gamble, P.E. and Mullet, J.E. (1989) EMBO J., 8, 2785-2794

6. Kuchka, M.R., Goldschmidt-Clermont, M., van Dillewijn, J. and Rochaix, J.-D. (1989) Cell, 58, 869-876.

7. Sexton, T.B., Christopher, D.A. and Mullet, J.E. (1990) EMBO J., 9, 4485-4494.

8. Dreyfuss, G., Swanson, M.S. and Pinol-Roma, S. (1988) Trends Biochem. Sci., 13, 86-91.
9. Dreyfuss, G. (1986) Annu. Rev. Cell Biol., 2, 459-498.

10. Bandziulis, R.J., Swanson, M.S. and Dreyfuss, G. (1989) Genes Develop., 3, $431-437$

11. Mattaj, I.W. (1989) Cell, 57, 1-3.

12. Dreyfuss, G., Philipson, L. and Mattaj, I.W. (1988) J. Cell Biol., 106, 1419-1425.

13. Birnstiel, M.L. (ed.) (1988) Structure and Function of Major and Minor Small Nuclear Ribonucleoprotein Particles. Springer-Verlag, Berlin.

14. Li, Y. and Sugiura, M. (1990) EMBO J., 9, 3059-3066.

15. Li, Y., Ye, L., Sugita, M. and Sugiura, M. (1991) submitted.

16. Pandolfo, P., Valentini, O., Biamonti, G., Rossi, P. and Riva, S. (1987) Eur. J. Biochem., 162, 213-220.

17. Pinol-Roma, S., Choi, Y.D., Matunis, M.J. and Dreyfuss, G. (1988) Genes Develop., 2, 215-227.

18. Swanson, M.S. and Dreyfuss, G. (1988) Mol. Cell Biol., 8, 2237-2241.

19. Hemsley, A., Arnheim, N., Toney, M.D., Cortopassi, G. and Galas, D.J. (1989) Nucl. Acids Res., 17, 6545-6551.

20. Gallie, D.R., Sleat, D.E., Watts, J.W., Turner, P.C. and Wilson, T.M.A. (1987) Nucl. Acids Res., 15, 3257-3273.

21. Kozak, M. (1986) Cell, 44, 283-292.

22. Laemmli, U.K. (1970) Nature, 227, 680-686.

23. Konarska, M.M. and Sharp, P.A. (1986) Cell, 46, 845-855.

24. Merrill, B.M., Stone, K.L., Cobianchi, F., Wilson, S.H. and Williams, K.R. (1988) J. Biol. Chem., 263, 3307-3313.

25. Michel, B. and Zinder, N.D. (1989) Nucl. Acids Res., 17, 7333-7344.

26. Buvoli, M., Cobianchi, F., Biamonti, G. and Riva, S. (1990) Nucl. Acids Res., 18, 6595-6600.

27. Stern, D.B. and Gruissem, W. (1987) Cell, 51, 1145-1157.

28. Stern, D.B., Jones, H. and Gruissem, W. (1989) J. Biol. Chem., 264, $18742-18750$.

29. Shinozaki, K., Ohme, M., Tanaka, M., Wakasugi, T., Hayashida, N., Matsubayashi, T., Zaita, N., Chunwongse, J., Obokata, J., Shinozaki, K.Y. Ohto, C., Torazawa, K., Meng, B.Y., Sugita, M., Deno, H., Kamogashira, T., Yamada, K., Kusuda, J., Takaiwa, F., Kato, A., Tohdoh, N., Shimada, H. and Sugiura, M. (1986) EMBO J., 5, 2043-2049.

30. Sugiura, M. (1991) In Bogorad, L. and Vasil, I.K. (eds.), Cell Culture and Somatic Cell Genetics of Plants. Academic Press, San Diego, Vol 7A, pp. $125-137$.

31. Nickelsen, J. and Link, G. (1989) Nucl. Acids Res., 17, 9637-9648. 